\title{
MRV of support: National keys actions for forests conservation and reforestations promotion in Burkina Faso from 1985 to 2015 to mitigate climate changes
}

\section{MRV de apoyo: Claves nacionales para la conservación de los bosques y la promoción de la reforestación en Burkina Faso desde 1985 hasta 2015 para mitigar el cambio climático}

DOI: 10.46932/sfjdv2n3-084

Received in: May 1st, 2021

Accepted in: Jun 30th, 2021

\author{
PhD Tiga NEYA \\ Ministry of Environment Green Economy and Climate Change of Burkina Faso \\ E-mail neyatiga@gmail.com /tigson2005@yahoo.fr \\ PhD Awassi Abungyewa \\ Kwame Nkrumah University of Sciences and Technology of Ghana Kumasi \\ E-mail: akwasi_abunyewa@yahoo.com \\ Idrissa SEMDE \\ Ministry of Environment Green Economy and Climate Change of Burkina Faso \\ E-mail : idsemde@gmail.com
}

\begin{abstract}
Land cover improvement constitutes an essential element for greenhouse gas removal in the atmosphere and constitute at the same time the most challenges for worldwide. This study aim to synthetize the national initiatives or actions developed and implemented to improve land cover from 1985 to 2015 through national implemented policies analysis. Results shown that during 30 last pass years' three key policies such as Policy Speech of 02 October 1983, Strategy for Poverty Alleviation and Accelerated Increasing Strategy and Sustainable Development with at least 10 important actions have been developed and implemented. Thereby, in term of protected area, 4.2 million hectare were created and conserved. For reforestation promotion, more than $63954.304 \mathrm{Kg}$ of trees seeds was harvested and more than 128116 182 trees plants were planted from 2002 to 2015 on 150316.54 hectares. Butane consumption promotion through household reduced considerably firewood and butane consumption ratio from 451 times in 2000 to 88 time in 2015. Implementations of those policies were contributed to reduce pressure on the forests and improve land cover and improved significantly Burkina Faso $\mathrm{CO}_{2}$ sequestration potential.
\end{abstract}

Keywords: Butane, policy, action, reforestation, $\mathrm{CO}_{2}$ sequestration Burkina Faso

\section{RESUMEN}

La mejora de la cubierta terrestre constituye un elemento esencial para la eliminación de los gases de efecto invernadero en la atmósfera y constituye al mismo tiempo el mayor desafío para el mundo. Este estudio pretende sintetizar las iniciativas o acciones nacionales desarrolladas e implementadas para mejorar la cubierta terrestre desde 1985 hasta 2015 a través del análisis de las políticas nacionales implementadas. Los resultados muestran que durante los últimos 30 años se han desarrollado e implementado tres políticas clave, como el Discurso Político del 2 de octubre de 1983, la Estrategia de Alivio de la Pobreza y la Estrategia de Aumento Acelerado y Desarrollo Sostenible, con al menos 10 acciones importantes. De este modo, se han creado y conservado 4,2 millones de hectáreas de zonas protegidas. Para la promoción de la reforestación, se cosecharon más de 6.954,304 kg de semillas de 
árboles y se plantaron más de 128.116.182 plantas de árboles entre 2002 y 2015 en 150.316,54 hectáreas. La promoción del consumo de butano a través de los hogares redujo considerablemente la proporción de consumo de leña y butano de 451 veces en 2000 a 88 veces en 2015. La aplicación de estas políticas ha contribuido a reducir la presión sobre los bosques y a mejorar la cobertura del suelo y a mejorar significativamente el potencial de secuestro de CO2 de Burkina Faso.

Palabras clave: Butano, política, acción, reforestación, secuestro de CO2 Burkina Faso.

\section{INTRODUCTION}

Greenhouse gas reduction is among the major developmental challenges in the world in general to combat climate change (IPCC,2014). Atmospheric carbon dioxide rising is cited as the main factor and cause of global warming (LINDZEN,2009). The rising of atmospheric carbon dioxide and other greenhouses gas has been attributed to human activities which release greenhouse gases such as carbon dioxide, methane and nitrous oxides in the atmosphere (IPCC, 2007b). Most developing countries are vulnerable to the effect of global warming and its consequences of climate variability and change due to the the lack of appropriate adaptation strategies. This is worse for rural populations because of their strong dependency on natural resources provision of services became unstable due to climate change (ADGER et al., 2003; IPCC 2007a; MERTZ et al., 2009; NHEMACHENA 2009; POULIOTTE et al., 2009). Furthermore, land use change, particularly forest conversion to cropland is among the major cause of deforestation (PIELKE et al., 2011). Deforestation has also been cited as one of the most influencing factors that has raised international environmental problems, such as global warming, loss of biodiversity and land degradation among others (FAO, 2003). On the other land, deforestation has an enormous impact on the 1,5-2 billion people who depend on trees for livestock fodder, fruits, habitat construction, cooking and heating fuel, medicines, religious and cultural practices (BONNER 1992, UICN 2004, NEYA 2006). An alternative to mitigate the disastrous effects of deforestation and to reduce climate change would be to develop strategies and policies to fight against deforestation and promote afforestation particularly in tropical dry-lands, where trees play a central role in the combat against desertification and climate change (BRETON WOOD 1992, NEYA 2006). It is that the convention of Climate change, Biodiversity and desertification were initiated respectively at international level to overcome environmental adversity in order to minimize climate change impact on the population and world economy. After the engagement at international level each country member's should develop his own strategies or policies at national level to fight against desertification and to contribute to overcome climate change. It is that Burkina Faso is endorsed respectively the three generation of Rio since 1992; 1993; 1994 and adopted some policies at national level. Despite, those initiatives there is no document which capitalizes the key action developed to constitute live memory in term of action developed by Burkina Faso to overcome environmental 
problem. Also, the awareness of pass and currently policies allowed the best planning for the future and future generation. This study aim to give an insight of (review) capital policies developed at national level and analyze some of implemented actions to safeguard and protect land cover resources, since 1985 to 2015; in order to synthetized the key actions developed to overcome global warming, promoting tree planting and forest conservation or management to guide future policymakers for decision and national policies orientations and to show policies support to increase land cover /land use management.

\section{MATERIAL AND METHOD}

\subsection{PRESENTATION OF BURKINA FASO}

Burkina Faso is a landlocked country in Africa around 274,200 square kilometres in size (figure 1). It is surrounded by six countries: Mali to the north; Niger to the east; Benin to the southeast; Togo and Ghana to the south; and Ivory Coast to the southwest. Its capital is Ouagadougou. In 2014 its population was estimated at just over 17.3 million. Burkina Faso is a francophone country and French is an official language of government and business. Formerly called the Republic of Upper Volta, the country was renamed "Burkina Faso" on 4 August 1984.

Figure 1: Burkina Faso location in Africa.

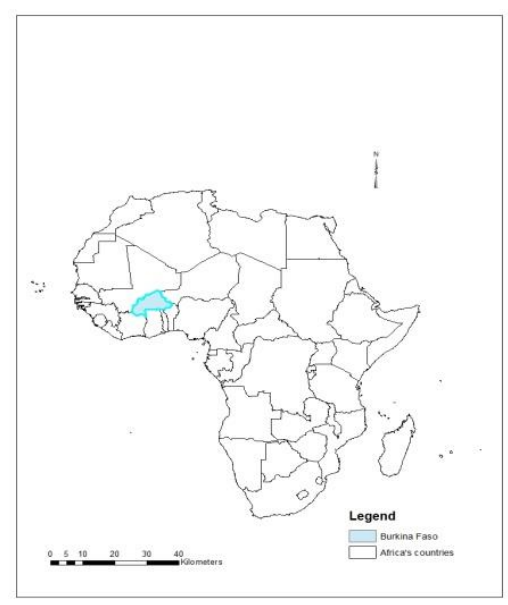

\subsection{METHOD}

It consisted to record available national policies developed and implemented from 1985 to 2015 . After the recorded document the information is collected through reading and all action or activities related to desertification and climate mitigation are identified even if some initiatives were done before the creation, three generations convention of Rio. A summary of key activities was made following the different period in order to constitute the historical evolution of action in term of mitigation to climate change and fight against desertification, and data on the results of those actions were collected with 
implemented offices in Burkina Faso for impact analysis. For data analysis Minitab software version 17 and sigma plot version 13.0 were used to design the figure and ANOVA one is used for statistical analysis of mean.

\section{RESULTS}

\subsection{IMPLEMENTED POLICIES FROM 1985 TO 2015}

From 1985 to 2015 three majors' strategies or policies at national scope can be retained.

\subsubsection{Policy Speech of 02 October 1983}

This policy was developed in order to promote sustainable environment in Burkina Faso, before the creation of three generation convention of Rio in 1992 such as Climate Change, Desertification and Biodiversity. Known the causes of deforestation and his consequences, three key actions such as Fight against wood logging, Fight against bush fire and Fight against animal herring were developed and implemented (Burkina Faso 1983). But all measures were dictatorial measures and compulsory for everybody without stakeholder's points of view. Indeed to consolidate the success story of three fights, to increase land cover and to develop participatory management of land, National Program for Land Management was initiated and implemented from 1990 to 1999. The mean action recorded in the planning document were respectively one village one forest so 8000 villages 8000 forests at this moment, one school one botanic garden and one village one local comity for land management (Burkina Faso 1990).

\subsubsection{Strategy for Poverty alleviation/Poverty Reduction Strategy}

This policy is developed and implemented from 2000 to 2010 to strengthen to build population resilience to climate change and to reduce population pressure on the forest in order to participate to the global effort to greenhouse gas reduction and to promote sustainable management of naturel resources. It is that, one household one cylinder and one household one improve stove have been developed (Burkina Faso 2000). Those actions are developed to reduce fire wood and charcoal utilization particularly in semiurban and urban area, the butane was subsidized to promote gas utilization in the household level; which contributes to reduce deforestation and dioxide carbon emission in the atmosphere. 


\subsubsection{Accelerated Increasing Strategy and Sustainable Development}

It was developed and implemented from 2010 to 2015 to strengthen the key action of CSLP and to promote some news initiatives. It is that one household one solar panel and one Bio-digester are developed and recorded in this document. Moreover some single action such as one couple married one tree planted was developed by the commune to promote vegetation cover in the city hall. Those actions have been developed and implemented to overcome environmental challenges in order to increase population resilience to climate change and to reduce greenhouses gas emission.

\subsection{KEY RESULTS OF THOSE POLICIES}

\subsubsection{Protected area}

Those actions allowed the conservation and the creation of 77 protected areas with 4.2 million hectares (figure 2).

Figure2: superficies of protected area per regions in Burkina Faso (Difor 2007)

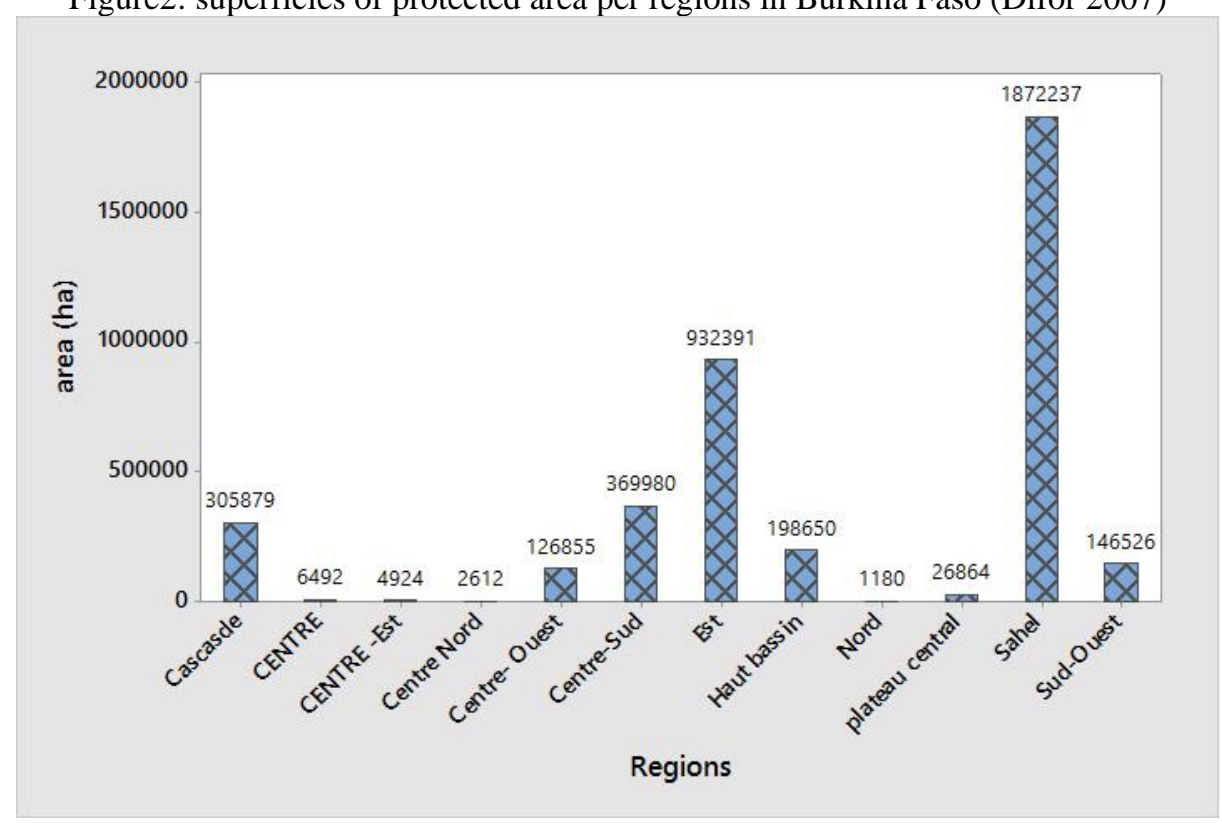

The high superficies of protected area is observed in the Sahel and the East region however the lower superficies are observed in the central part and the North of the Country.

\subsubsection{Planting promotion}

To promote tree plantation in the country, specific center such as National Trees Seeds Center (NTSC)/Centre National des Semences Forestières (CNSF) was created since 1984 in order to harvest, to store forest tree seed in ex situ or in situ and to promote local trees production in the nurseries for 
national plantation campaign. From 2002 to 2015 the center produces in total n $63954.304 \mathrm{~kg}$ of trees seed with $52550.87 \mathrm{Kg}$ of seed disseminated and more than 3082129 of plants produced in nurseries (table 1).

Table 1: contribution of National Trees Seeds Center for reforestation in Burkina Faso

\begin{tabular}{|l|l|l|l|l|l|}
\hline years & $\begin{array}{l}\text { Quantity of seeds } \\
\text { harvested }(\mathrm{kg})\end{array}$ & $\begin{array}{l}\text { Quantity of seed } \\
\text { disseminated }(\mathrm{kg})\end{array}$ & $\begin{array}{l}\text { Number of } \\
\text { species }\end{array}$ & $\begin{array}{l}\text { Leader species } \\
\text { disseminated }\end{array}$ & $\begin{array}{l}\text { Plants } \\
\text { produced }\end{array}$ \\
\hline 2002 & 3420.762 & 2794.31 & 45 & 23 & - \\
\hline 2003 & 5316.263 & 4059.08 & 66 & - & - \\
\hline 2004 & 3345.119 & 1923.03 & 48 & 26 & 334107 \\
\hline 2005 & 3355.53 & 2826.9 & 45 & 21 & 380275 \\
\hline 2006 & 3950.56 & 2564.97 & 63 & - & 132273 \\
\hline 2007 & 4480.51 & 3940.38 & 54 & 26 & - \\
\hline 2008 & 3814.16 & 3447.33 & 39 & 21 & - \\
\hline 2009 & 5676 & 4798.44 & 96 & 35 & 377299 \\
\hline 2010 & 4850 & 3414.21 & - & - & - \\
\hline 2011 & 5651.67 & 4984.19 & 70 & 37 & 334455 \\
\hline 2012 & 6335.87 & 3813.48 & 73 & 35 & 97637 \\
\hline 2013 & 4095.62 & 4332.84 & 68 & 30 & 256373 \\
\hline 2014 & 3865.93 & 3466.1 & 95 & 48 & 445155 \\
\hline 2015 & 5796.31 & 6185.61 & 68 & 35 & 724555 \\
\hline Total & $\mathbf{6 3 9 5 4 . 3 0 4}$ & $\mathbf{5 2 5 5 0 . 8 7}$ & & & $\mathbf{3 0 8 2 1 2 9}$ \\
\hline
\end{tabular}

- : lack of data/missing data

3.2.2.1Woody species used for reforestation.

Knowing that the reforestation contribute highly to improve vegetation cover and improve the capability of greenhouse gas sequestration, tree planting has been adopted and each year some number of tree are produced and planted. More than 150 species were produced and used for reforestation in countrywide. Indeed, most of woody species used each years are: Acacia albida, Acacia nilotica, Adansonia digitata, Afzelia africana ,Albizia lebbeck, Anacardium occidentale, Azadirachta indica, Balanites aegyptiaca, Bombax costatum, Ceiba pentandra, Detarium microcarpum, Eucalyptus camaldulensis ,Lannea microcarpa, Mangifera indica, Parkia biglobosa, Prosopis juliflora , Tamarindus indica. From 2002 to 2015 environ 128116182 woody species composed by exotic and local species were produced and planted (figure3). However the contribution of NTSC represented less than $3 \%$ of total plants used for reforestation during the last fourteen years. The others plants have been cover by the NGO's and private sectors which contribute to generate news jobs for youths. Assuming the mean price of one plant to $100 \mathrm{CFA}$, the 128116182 will represent $12811618200 \mathrm{~F} \mathrm{CFA}$, so $6.4 \%$ of national budget in 2015. 
Figure 3: type of woody species planted.

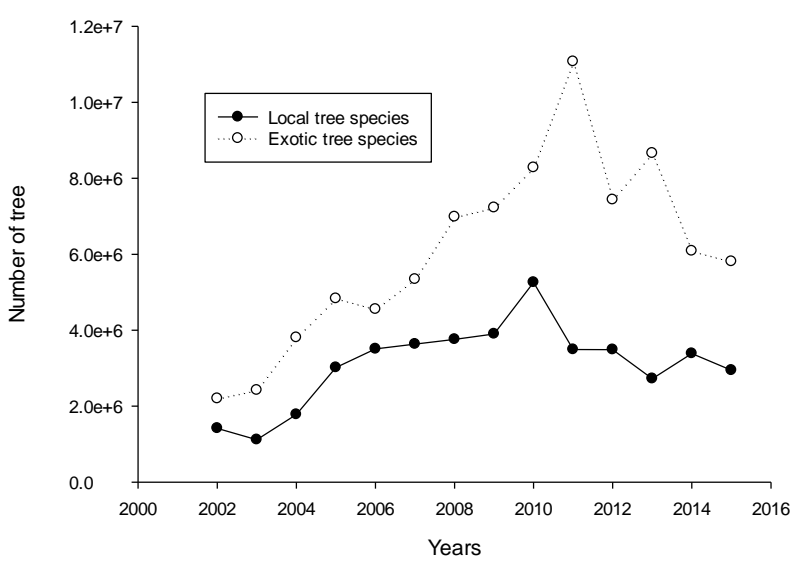

Among those species, the most are exotics tree species, some are multipurpose tree eg agroforestry species and only Anacardium occidentale and Mangifera indica are horticulture species.

\subsubsection{Evaluation of planting promotion system}

\section{Merits}

The following merits can be cited: Existence of national Specialize centres such as National Trees Seeds Centre and National Centre for Scientific Research and Technologic (NCSRT)/ Centre National de la Recherche Scientifique et Technologique (CNRST) to develop Scientifics research in order to facilitate tree domestication and improve the regeneration method; the development of private nurseries and national and international NGO's in all the countryside to promote tree planting; Annual plantation campaign organization by the government; the high number of trees species diversity used.

\section{Weaknesses.}

The most of annual plantation campaign organized by the government are folkloric; the mismatched of plants used for plantation and local population needs and or the no adaptability trees species used form one site to another; the lack of standard monitoring system to evaluate annual survival rate and to report in order to appreciate the results; the lack of information on each tree species such as botanical aspect (phenology, morphology), site preferences, management aspects and type of specific services/products allocated for each plantation campaign and the upkeep of trees after their plantation.

\section{Potential for improvement}

Given that the first beneficiary are local population, a survey on the tree species need for the household should be done before the plantation activities that will avoid folkloric plantation and allow farmers to promote agroforestry or to plant trees that they need sometime. Elaborate a standard framework for monitoring and national report, that allow long series data analysis of the action. To establish National 
Multipurpose Tree Databases for the entire thirteen regions and update them each three years following the stepwise approach for multipurpose trees identification (figure4).

Figure 4: Stepwise approach for multipurpose trees identification

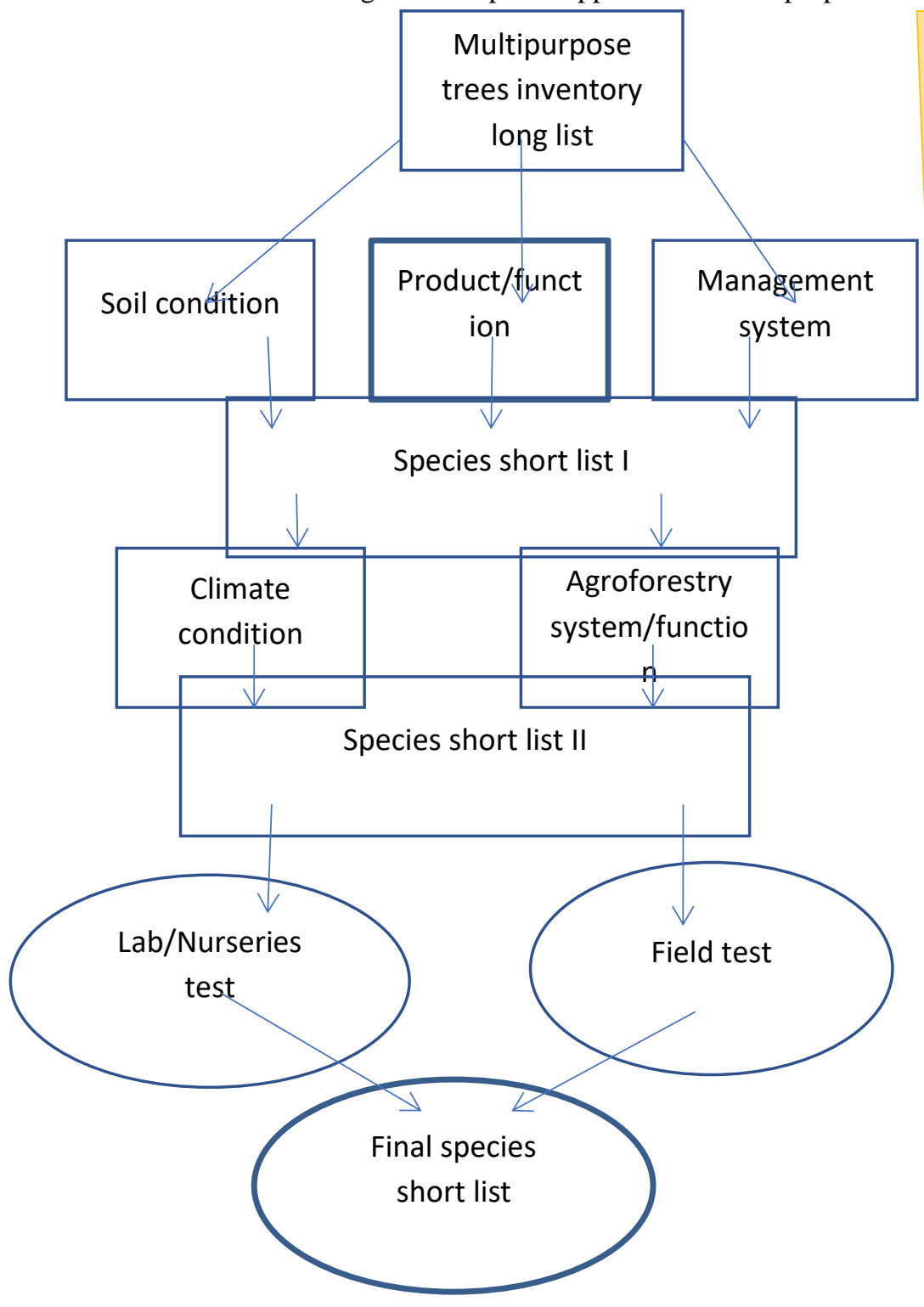




\subsubsection{Charcoal, Firewood and Butane consumption trend}

From 2000 to 2015 firewood consumption increase exponentially and Charcoal and butane increase logarithmically (figure 5). The butane has been subvention to reduce firewood consumption. That, has contributed to increase the demand and to increase it importation but the statistical analysis with One-way ANOVA (P-Value < 0.115) showed that, there is no significant different between the mean of the imported quantity of butane from 2000 to 2009 and 2010 to 2016 despite infatuation provoked

Figure 5: Charcoal, fire wood and butane consumption trend

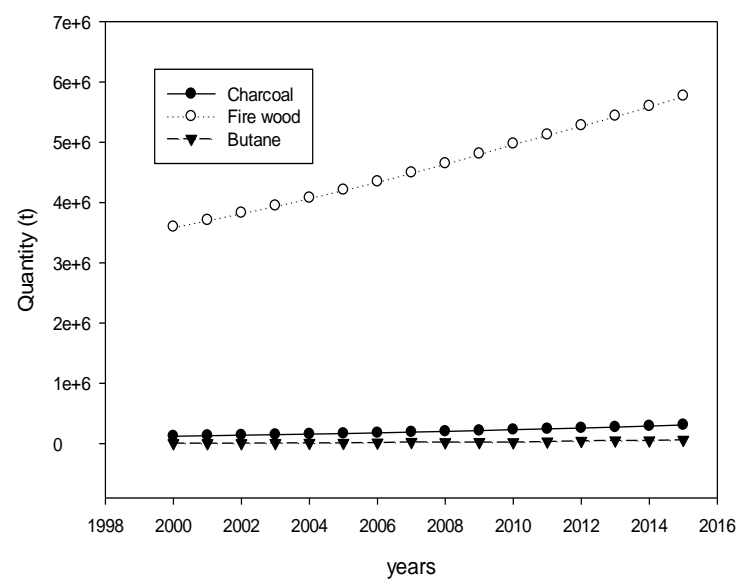

The curve of firewood consumption revealed that it substitution by butane stay far away and firewood consumption has been estimated to 451 time the quantity of butane in 2000 and decrease to 88 time in 2015 (figure 6).

Figure 6: fire wood and butane consumption ratio trend.

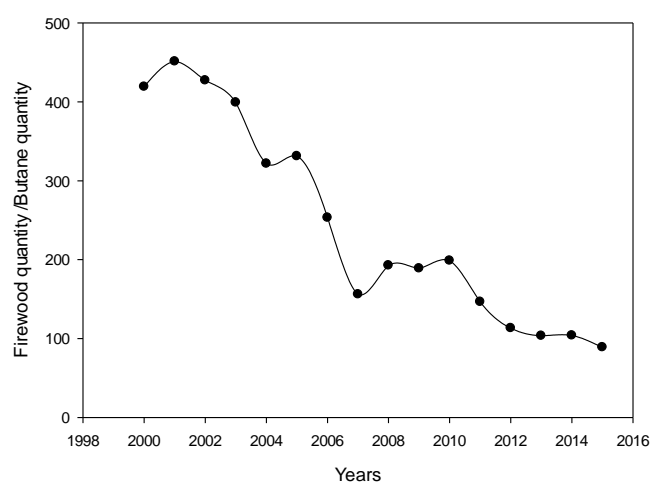




\subsection{FIREWOOD AND BUTANE DEMAND TENDENCY}

The projection of fire wood and butane demand from 2016 to 2026 shown that firewood trend will stay under the trend of butane despite the subvention effort of the government (figure 7).

Figure 7: firewood and butane demand for the next decade

\section{DISCUSSION}

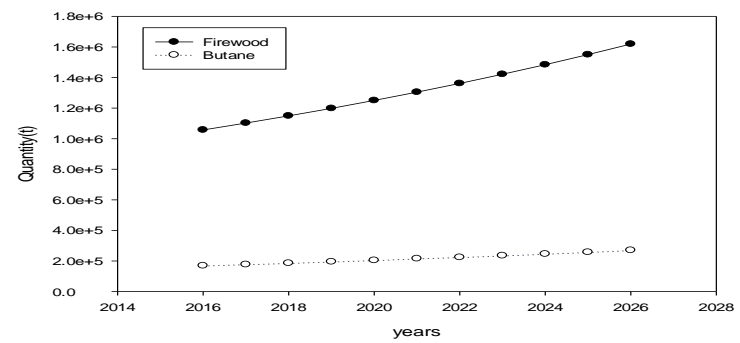

The higher surface of protected area observed respectively in Sahel and East region could be explain by lower density of population in Sahel and East region than the central part where the population are more concentrated or the rate of urbanization is higher, which increase land need for other type of use (INSD 2006). In this protected areas some activities such as bush fire wood logging, charcoal production, and animal herring are regulated and forbid something. These regulations contribute to reduce the emission of greenhouse gas emission cited such us the mean causes of gas emission and improve vegetation cover which contributes/leading to increase the capability of carbon sink. It was then, argued that forest and other vegetation cover constitute the potential source of greenhouses gas removal in the atmosphere and considered as important reservoir of carbon sink (IAASTD, 2009; MIGUEL, 2011; IPCC, 2006; Neya 2020). Moreover, Africa has been called fire continent because of higher spread rate of bush fire (TROPPLOPE \& TROPPLOPE 1996; MBOW et al; 2000; REID et al; 2000; LARIS 2002; DANTHU et al 2003). However, it was argued and supported that bush fire contributes significantly to atmospheric greenhouses gases emission (Shimada et al.2000) and savanna burned area was estimated to 1900 million hectares (BOLIN et al; 1979) with emission rate of methane (Ch4) and monoxide carbon (CO) estimated at 0.001719 ton per hectare and 0.045119 ton per hectare respectively (EMMANUEL et al; 2015; Neya 2018). So, fight against bush fire constitute in important action to reduce greenhouses gas emission /release in the atmosphere and to fight against desertification. Knowing that, bush fire causes are usually natural and anthropogenic (JONES 1979; LANGAAS 1995) the initiative of local comity of land management developed was to empower the community to develop their own initiative to minimize bush fire and to develop some activity which contribute to their wellbeing and diversify their source of income. Indeed, many authors were argued that African pastoralists and farmers have developed traditional way of avoiding, the overwhelming nature fire such as early season grass burning in order to green flush from perennial grasses for their livestock (MBOW et al;2000; BUCINI \& LAMBIN 2002; EMANNUEL et al 
2015 ). Additionally, fire wood and charcoal production relates to climate change in terms of role played by woodlands and forests in the global carbon cycle (CLARK et al., 2008; IPCC, 2006). Moreover the woodlands and forests serve as stocks and sinks of $\mathrm{CO} 2$ depending on how they are used and managed (FORSTER et al., 2007; IPCC, 2006; ROOP, 2013; Neya 2020). The decreasing tendency of firewood and butane ratio over the year showed the willpower of all the stakeholders to inverse the ratio tendency but the projection trend of firewood and butane demand revealed that firewood will still the principal source of energy at household level for the next decade (figure 8). The results corroborate with the findings of PARKAN (1986) and OUEDRAOGO (2000) who reported decreasing of firewood consumption at 1.65 to 1.5 and 90 gram per year respectively and increasing of butane consumption in the urban area of Burkina Faso. To inverse drastically this tendency more effort should be developed again by policymakers in order to improve butane availability and it accessibility to low income households. It was revealed and reported by MEEVCC (2017) that despite the subvention of butane, it price still stay higher for the majority of households who have low income. However the same author noted the same year, that butane promotion, allowed the reduction of $12 \%$ of firewood and charcoal consumption in thirteen mega cities in Burkina Faso such as Ouagadougou, Bobo_dioulasso, Ouahigouya, Gaoua .... View, the growing demand for firewood; the promotion of tree planting has been a major action in development policies in Burkina Faso.

The hundred species produced and used in the reforestation, can be explained by the high diversity of woody species found in the countryside (MECV 2007). Indeed the 150 species promoted in the plantation represented only $4 \%$ of the potentiality in term of woody species, because 376 woody species were recorded (MECV 2007). Despite the promotion of local species, the number of exotics species still stays higher (figure 2). NEYA (2006) showed that the highly grow of exotics species constitute the means reason of their used even if they are not multipurpose trees for local population. Most plantations are based on seedlings grown in nurseries (Gaméné, 1987). However, it was showed that plantations and domestication of local species are confronted with sociocultural constraints and insufficient of scientific knowledge about the ecology of regeneration of indigenous species (BATIONO, 2002). The success of reforestation based on plant production in nurseries requires a good knowledge of physiology of plant material used (NEYA 2017). In addition, a good knowledge of seed biology, physiology, constraints on germination and conservation are an essential prerequisite for rational, sustainable use and enhanced valorisation of local species (NEYA, 2017; NEYA 2018). Furthermore, the persistence of the use of local species in the reforestation campaigns could also be explained by their adaptability to environmental conditions, which augured better survival rates or by their multiple used for the farmers. 


\section{CONCLUSION}

Implementation of these policies has significantly reduced the pressure on forests by improving vegetation cover and also contributed to reduce firewood-butane consumption ratio from 451 times in 2000 to 88 times in 2015. However, the price of the butane gas despite the subsidy remains inaccessible to the poorest households. This situation keeps fuelwood demand up for the next decade. Some research should be done to characterise agroforestry profiles in order to guide future actions in term of reforestation and to make them more useful and profitable for low income farmers.

\section{CONFLICT OF INTEREST}

No conflicts of interest to declare.

\section{ACKNOWLEDGEMENTS}

Authors thank West African Science for Climate Change and Adapted Land Use and Germany Republic for their financial support to this research. 


\section{REFERENCES}

ADGER, W.N., Hug S.Brown K., Conway D., Hume M. (2003). Adaptation to climate change in developing world. Prog Dev Stud 3:179-195.

ARNOLD, M. and PERSSON, R. (2003). Reassessing fuelwood situation in developingcountries International Forestry review, 5: $379-383$.

BATIONO B.A. (2002). Régénération naturelles et fonctionnement des espèces ligneuses dans la forêt classée de Nazinon (Burkina Faso) : Detarium microcarpum (Guill.et Perr), Afzelia africana (Sm).,Isoberlinia doka (Craid et Stapf)., Piliostigma thonningii (Sch Miln Redh) et Terminalia avicenioides (Guill et Perr). Thèse de 3èm cycle. Université de Ouagadougou.165p.

BONNER, T.(1992) .Seed technology : A challange for tropical forest. Trees planters' Note. 4p.

BOLIN, B., DEGENS, E.T DUVIGNEAUD, P., \& KEMPE, S. (Ed) (1979). The global carbon cycle. SCOPE Report, 13,1-56. Weley, Chichester, England.

BROADHEAD, J., BAHDON, J. and WHITEMAN, A. (2001). Woodfuel consumption modeling and results. Annex 2. In: Past trends and future prospects for the utilization of wood for energy. GFPOS/WP/05, global forest products outlook study.

BUCINI, G., \& LAMBIN, E.F. (2002). Fire impact on vegetation in central Africa. A remote sensing based statistical analysis. Applied geography, 22(1),27-48. Doi.10.1016/S0143-6228(01)00020-0

Burkina Faso (1983). Le discours d orientation du 02 octobre 1983. 5 p.

Burkina Faso. (1990) : Programme National de gestion de terroir. 60p.

Burkina Faso. (2000) . Cadre Strategique de Lutte contre la Pauvrete. 55 p.

Burkina Faso. (2010). Strategie de Croissance Acceleree et du Developpement Durable.

CLARK, S., Bolt, K. and CAMPBELL, A. (2008). Protected areas: an effective tool to reduce emissions from deforestation and forest degradation in developing countries? Working Paper, UNEP World Conservation Monitoring Centre, Cambridge, U.K.

EMANNUEL, N., EZENWA, I.S.M., NYARKO, K., BENJAMIN, A.A.O., BAGAMSAH, T. T., \& OKELLOLA O. F. (2015). Assessment of trace gas from wild fires in different vegetation types in northern Ghana: Implication for Global Warming.

FAO (2003) Responding to agricultural and food insecurity challenges mobilizing Africa to implement Nepad Programmes FAO. Maputo, Mozambique.

FORSTER, P., RAMASWAMY, V., ARTAXO, P., BERNTSEN, T., BETTS, R., FAHEY, D. W., HAYWOOD, J., LEAN, J., LOWE, D. C., MYHRE, G., NGANGA, J., PRINN, R., RAGA, G., SCHULZ, M., and VAN DORLAND, R., (2007): Changes in Atmospheric Constituents and in Radiative Forcing.In: Climate Change 2007: The Physical Science Basis. Contribution of Working Group I to the Fourth Assessment Report of the Intergovernmental Panel on Climate Change [Solomon, S., Qin, D., Manning, M., Chen, Z., Marquis, M., Averyt, K. B., Tignor, M., and Miller, H. L. (eds.). Cambridge University Press, Cambridge, United Kingdom and New York, NY, USA. 
GAMENE C.S., (1987). Contribution à la maîtrise des méthodes simples de prétraitements et de conservation des semences de quelques espèces ligneuses récoltées au Burkina Faso. Mémoire de fin d'études IDR/UO.96p.

Juan C. G. M; Ender J.B.M; Lloyd H. M.M (2021): Impact of air transport on climate change. South Florida Journal of Development Miami, v.2, n.3, p. 4029-4047 special edition, jul. 2021. ISSN 26755459. DOI: $10.46932 /$ sfjdv2n3-018

IAASTD (International Assessment of Agricultural Knowledge, Science and Technology for Development) (2009) Agriculture at a Crossroads.In: International Assessment of Agricultural Knowledge,Science and Technology for Development Global Report, Island Press, Washington, D.C.

IPCC (2007a) Climate change 2007: impacts, adaptation and vulnerability. Cambridge University Press, Cambridge IPCC. 2006. IPCC Guidelines for national greenhouse gas inventories. Agriculture. Forestry and Other Land Uses 4. http://www.ipcc-nggip.iges.or.jp/public/2006gl/vol4.html.

IPCC. ( 2007b). Climate Change: Synthesis Report. Contribution of Working Groups I, II and III to the Fourth Assessment Report of the Intergovernmental Panel on Climate Change. Geneva: Intergovernmental Panel on Climate Change, $52 \mathrm{p}$.

IPCC.( 2006). IPCC Guidelines for national greenhouse gas inventories. Agriculture. Forestry and Other Land Uses 4. http://www.ipcc-nggip.iges.or.jp/public/2006gl/vol4.html.

IUCN. (2004). 2004 red list of threatened species. [at http:// www.redlist.org]

Jones. R. (1979). Annu Rev Anthropol ., 8,445. http://dx.doi.org/10.1146/annurev.an.08.100179.002305 LANGAAS, S. (1995). Night-time observation of west Africa bushfire from space. Study on method and application of Thermal NOAA/AVHRR Satelite data from Senegal and Gambia. Thesis/Dissertation, Department of Geography, University of Oslo, Norway.

LARIS, P. (2002). Burnning the seasonal mosaic: preventive burning strategies in the wooded savana of southern Mali. Human ecology.30,155-186. http://dx.doi.org/10.1023/A:1015685529180

LINDZEN, R. (2009). On the observational determination of climate sensitivity and its implications, (August), 19-23.

MARANZ, S.( 2009). Tree mortality in the African Sahel indicates an anthropogenic ecosystem displaced by climate change. Journal of Biogeography, 36: 1181-1193.Nair P.K.R., 2001. Do tropical homegardens elude science or is it the other way around. Agroforestry Systems, 53: 239-245.

MASERA, O., GHILARDI, A., DRIGO, R. and TROSSERO, M. A. (2006). WISDOM: A GIS-based supply demand mapping tool for woodfuel management. Biomass and Bioenergy, 30: 618 - 637 .

MBOW, C., NIELSEN, T.T., \& RASMUSSEN, K. (2000). Savana fire in eat central Senegal. Distribution partterns, resources managment and perception. Human ecology, 28(4), 561-583. http://dx.doi.org/10.1023/A:1026487730947.

MEEVCC.(2015). Cotribution National Determine 50p. 
MIGUEL, A. ALTIERI , R. PAULO P. (2011). Agroecologically efficient agricultural systems for smallholder farmers: contributions to food sovereignty Agron. Sustain. Dev. (2012) 32:1-13 DOI 10.1007/s13593-011-0065-6.

NEYA, O., (2006). Conservation of Tree Seeds from Tropical Dry-Lands. PhD thesis, Wageningen University and Research Centre. Wageningen, The Netherlands, 159p.

NEYA, T., DABOUE, E., NEYA, O., \& OUEDRAOGO, I. (2017). Germination Characteristics of Parinari curatellifolia Planch . Ex Benth, Vitex doniana Sweet and Zanthoxylum zanthoxyloides ( Lam ) Watermann Seeds, 12(3), 1-12. https://doi.org/10.9734/ARRB/2017/32209

Neya, T., Abunyewa, A.A., Neya, O. et al. Carbon Sequestration Potential and Marketable Carbon Value of Smallholder Agroforestry Parklands Across Climatic Zones of Burkina Faso: Current Status and Way Forward for REDD+ Implementation. Environmental Management 65, 203-211 (2020). https://doi.org/10.1007/s00267-019-01248-6

NHEMACHENA, C., (2009) Agriculture and future climate dynamics in Africa: impacts and adaptation options. Ph.D. Thesis.Department of Agricultural Economics, Extension, and Rural Development, University of Pretoria, South Africa.

OUEDRAOGO, B., (2000). La demande de bois-énergie à Ouagadougou : esquisse d'évaluation de l'impact physique et des échecs des politiques de prix, Développement durable et territoires, Varia, 20 mars 2006. 52p

PARKAN, J. et al. (1986), Bilan et évolution des disponibilités en bois -Alternatives des productions forestières et d'actions sur la consommation, Rapport de synthèse, FAO, Rome. 25 p.

PIELKE Sr., R.A., A. PITMAN, D. NIYOGI, R. MAHMOOD, C. MCALPINE, F. HOSSAIN, K. GOLDEWIJK, U. NAIR, R. BETTS, S. FALL, M. REICHSTEIN, P. KABAT, and N. de NobletDucoudré,. (2011). Land use/land cover changes and climate: modeling analysis and observational evidence, Wiley Interdiscip. Rev.-Clim. Chang., 2(6), 828-850, doi:10.1002/wcc.144

POULIOTTE, J., SMIT B., WESTERHOFF, L. (2009). Adaptation and development: livelihoods and climate change in Subarnabad, Bangladesh. Clim Change Dev 1:31-46.

REID, R.S., KRUSKA, R.L., MUTHUI, N., TAYE, A., WOTTON, S., WILSON, C. J., \& MULATU, W. (2000). Land use and land cover dynamic in response to change in climatic , biological and socio-political forces: the case of southwestern Ethiopia. Landscape ecology, 15,339-355. Http://dx.doi.org/10.1023/A1008177712995.

ROOP, J. T. (2013). Moving Toward Sustainable Production of Charcoal in Sub-Saharan Africa: A Teaching Case Study. Chemistry Publications and Other Works. http://trace.tennessee.edu/utk_chempubs/38, accessed on 09th April 2017.

SHIMADA, S., TAKAHASHI, H., KANEKO, M., \& HARAGUCHI, A.(1999). The estimation of carbon resource in the tropical peatland. A caes study in central kalimantan, Indonesia. In Proceeding of the international symposium on Tropical peatland, Bogor, Indonesia (pp.9-18) 
TROLLOPE , W. S. W., \& TROLLOPE, L. A. (1996). Fire in african savana and other grazing ecosystems. Paper presented at the seminar on 'forest fire and global chang' held in Shusenskoye in the Russian federation from $4^{\text {th }}-10^{\text {th }}$ August 1996. 